\title{
Development of Peach Flower Buds under Low Winter Chilling Conditions
}

\author{
Gener A. Penso ${ }^{1, * \mathbb{D}}$, Idemir Citadin ${ }^{2} \mathbb{D}$, Silvia Scariotto ${ }^{2}$, Carlos E. Magalhães dos Santos ${ }^{1}$, \\ Américo W. Junior ${ }^{2} \mathbb{D}$, Claudio H. Bruckner ${ }^{1}$ and Javier Rodrigo ${ }^{3,4} \mathbb{D}$ \\ 1 Department of Agronomy, Federal University of Viçosa, Viçosa Campus, Viçosa - MG 36570-900, Brazil; \\ carlos.magalhaes@ufv.br (C.E.M.d.S.); claudio.bruckner@gmail.com (C.H.B.) \\ 2 Agronomy School, Federal Technological University of Paraná (UTFPR), Programa de Pós-Gradaduação \\ em Agronomia, Pato Branco Campus, Pato Branco - PR 85503-390, Brazil.; idemir@utfpr.edu.br (I.C.); \\ silviascariotto@yahoo.com (S.S.); americowagner@utfpr.edu.br (A.W.J.) \\ 3 Horticulture Unit, Agrifood Research and Technology Centre of Aragon (CITA), Avda. Montañana 930, \\ 50059 Zaragoza, Spain; jrodrigo@aragon.es \\ 4 AgriFood Institute of Aragon - IA2 (CITA- University of Zaragoza), Calle Miguel Servet 177, \\ 50013 Zaragoza, Spain \\ * Correspondence: generpenso@gmail.com
}

Received: 24 February 2020; Accepted: 17 March 2020; Published: 20 March 2020

check for updates

\begin{abstract}
Here, we reviewed both endogenous and exogenous factors involved in the processes of flower bud formation and flower development in peach, analyzing how they can be affected by climatic change in temperate zones, explored the expansion of peach to tropical or subtropical zones. The process of flower bud formation in peach differs between low winter chilling and temperate conditions. Although the main steps of flower development are maintained, the timing in which each one occurs is different, and some processes can be altered under low winter chilling conditions, with a great impact on fruit production and crop management. Further studies on flower bud induction and differentiation under warmer conditions are fundamental for addressing the alterations in flower bud development that negatively impact on next season's harvest. In the future, horticulturalists and scientists will face several challenges, mainly how high temperatures affect the expression of the main genes regulating flower formation and how to improve crop management in these conditions.
\end{abstract}

Keywords: climate change; morphogenesis; Prunus persica; flower induction; flower differentiation; warm climate; tree phenology

\section{Introduction}

Peach (Prunus persica (L.) Batsch) is one of the most economically important temperate zone fruit trees worldwide, with more than 39 million produced on 2.3 million ha. The main producing countries are China (more of 14 million $\mathrm{t}$ from 780,000 ha), Spain (1.8 million $\mathrm{t}$ from 84,000 ha), Italy (1.2 million $\mathrm{t}$ from $67,000 \mathrm{ha}$ ), and Greece ( 0.9 million $\mathrm{t}$ from $44,000 \mathrm{ha})$. The highest yields are obtained in Jordan (25 t/ha), France (23t/ha), Greece (22.8 t/ha), and Spain (21.3 t/ha) [1].

The lower availability of winter chilling in some temperate regions has caused irregular flowering and smaller and more variable production, with lower fruit quality [2-4]. Likewise, peach tree cultivation is expanding to subtropical and tropical regions. Thus, 19 of the 58 countries producing more than $10,000 \mathrm{t} /$ year have some subtropical or tropical areas with low winter chilling accumulation. The expansion of new areas allows the prospect of an increase in world production in the future [5-7]. However, some of these areas have little winter chilling, and some of them 
have previously been considered marginal, presenting cultivation limitations mainly due to the lack of winter chilling but also due to the instability of environmental conditions among years and locations [8,9]. Such characteristics may cause high yield oscillations hindering the agroclimatic zoning for new cultivars. However, some of these new areas have great potential for peach growing from an economic point of view, because their climatic conditions can provide early production in strategic seasons when there is a low supply of fruits, but there is a lack of information about peach cultivation under these conditions.

Peach tree developmental stages most affected under subtropical and tropical conditions are dormancy and dormancy break, resulting in alterations of flowering and effective fruiting, along with branch growth and development $[10,11]$. The formation of buds may also be affected, especially flower buds, which often are not fully formed, and these undeveloped flower buds form "blind nodes" [12-15]. The alterations in flower bud formation may cause lack of yield in the following season [16].

Different strategies have been used to expand peach cultivation to subtropical and tropical zones with low winter chilling accumulation, including the introduction of new low-chilling cultivars from breeding programs [17], and the use of cultural practices such as the application of dormancy breaking agents, e.g., hydrogen cyanamide, and hydric deficit [6,13,18-21]. However, problems regarding fruit set and production stability persist, possibly because they are associated with inadequate flower formation resulting from alterations during the different phases of flower development [9].

Understanding the factors controlling the formation of buds, such as the flower induction, initiation, and differentiation stages, is fundamentally important to search for effective solutions to these production problems as well as to support breeding programs and cultivation management [22,23]. Information on the bud formation process and its interactions with the environment is still unclear in peach and other temperate fruit species, especially when grown in subtropical and tropical climate regions.

Knowledge about the process of peach floral bud formation under these new conditions will provide a basis for solving future problems in temperate regions, recognizing the current climate change scenario [24-27]. Although several works have reported information about the process of floral bud development in peach and other Prunus species in warmer regions other than the traditional ones in Europe, there is little information about this process under tropical conditions such as those existing in different production regions in Brazil. The objective of this review is to provide information on the factors that interact with flower bud formation in peach under reduced winter chilling conditions.

\section{Formation of Buds}

Flower and vegetative buds in peach are formed on one-year-old branches where the plant growth has occurred over the previous growth cycle [28]. Therefore, all biotic and abiotic interactions that occur during this period may affect the formation of buds in the subsequent cycle.

Vegetative buds assure the survival of the plant once branches and leaves are formed which supply assimilates to the other plant structures [29-31]. In turn, flower buds produce flowers and fruits. Development of floral buds in peach takes place during several months from midsummer of the previous year to flowering in the following spring. Flower buds are located in the petiole axils (Figure 1a), and their differentiation starts during the vegetative growth period (Figure 1b). Flower differentiation is completed before winter dormancy (Figure 1c), which culminates with budbreak and anthesis (Figure 1d). Each vegetative bud is usually flanked by a pair of flower buds (Figure 1c,d), although this distribution may vary depending on the branch and the cultivar [30,32]. Vegetative buds appear to be smaller, conically shaped, and slightly covered by trichomes. On the other hand, flower buds are larger with a globe shape and an intense trichome layer [28].

In tropical and subtropical areas with early heat accumulation after dormancy breaking, vegetative growth begins earlier than in temperate regions [33], and flower budburst occurs rapidly (Figure 2). 


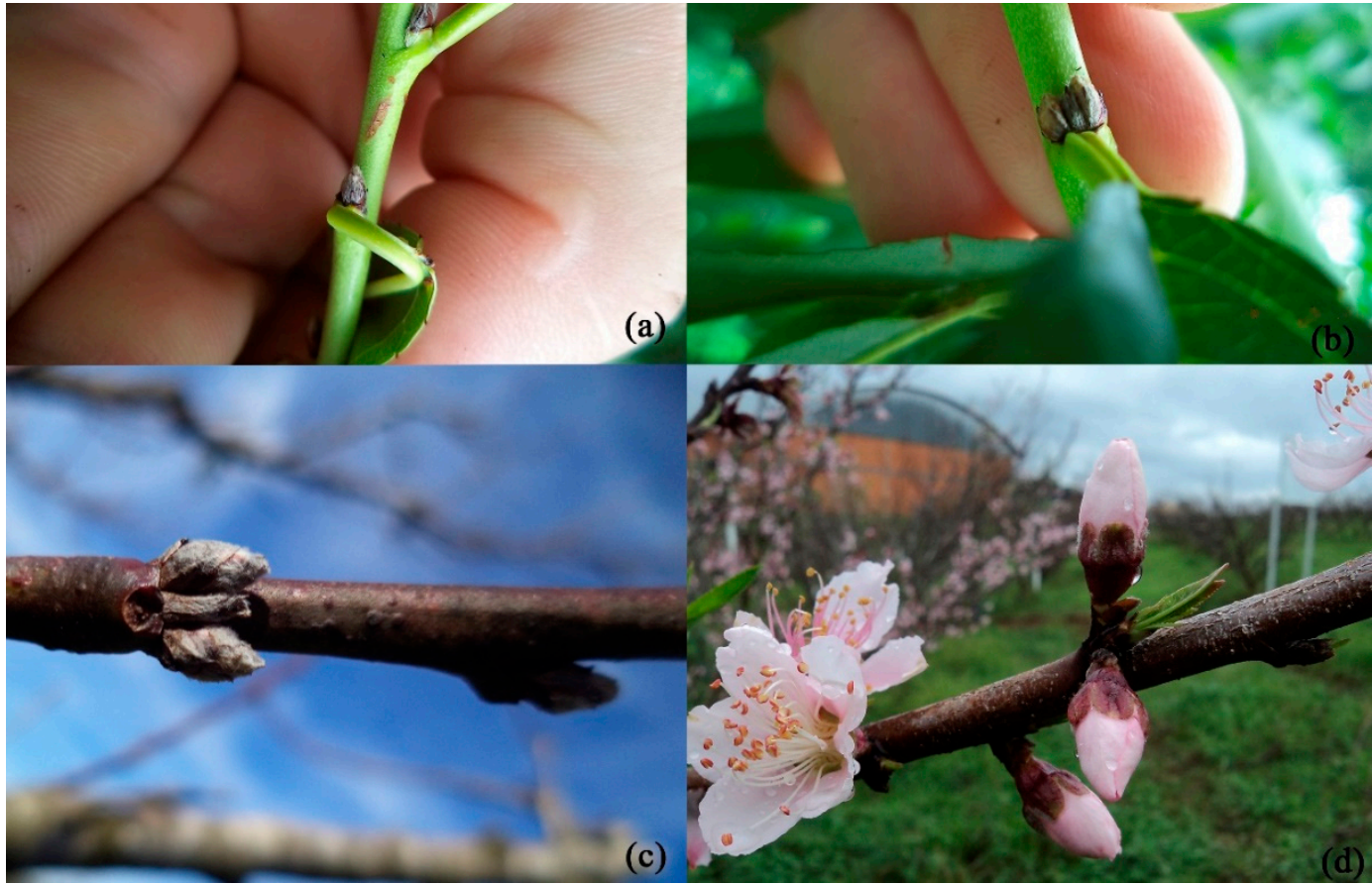

Figure 1. Developmental phases of flower and vegetative buds in peach. (a) The onset of flower differentiation; buds are apparent in the leaf axis. (b) Differentiated buds before dormancy. (c) During dormancy, flower buds remain closed without any apparent change. (d) At flowering, the petals open completely, the stigma is receptive, and the anthers dehisce their pollen.

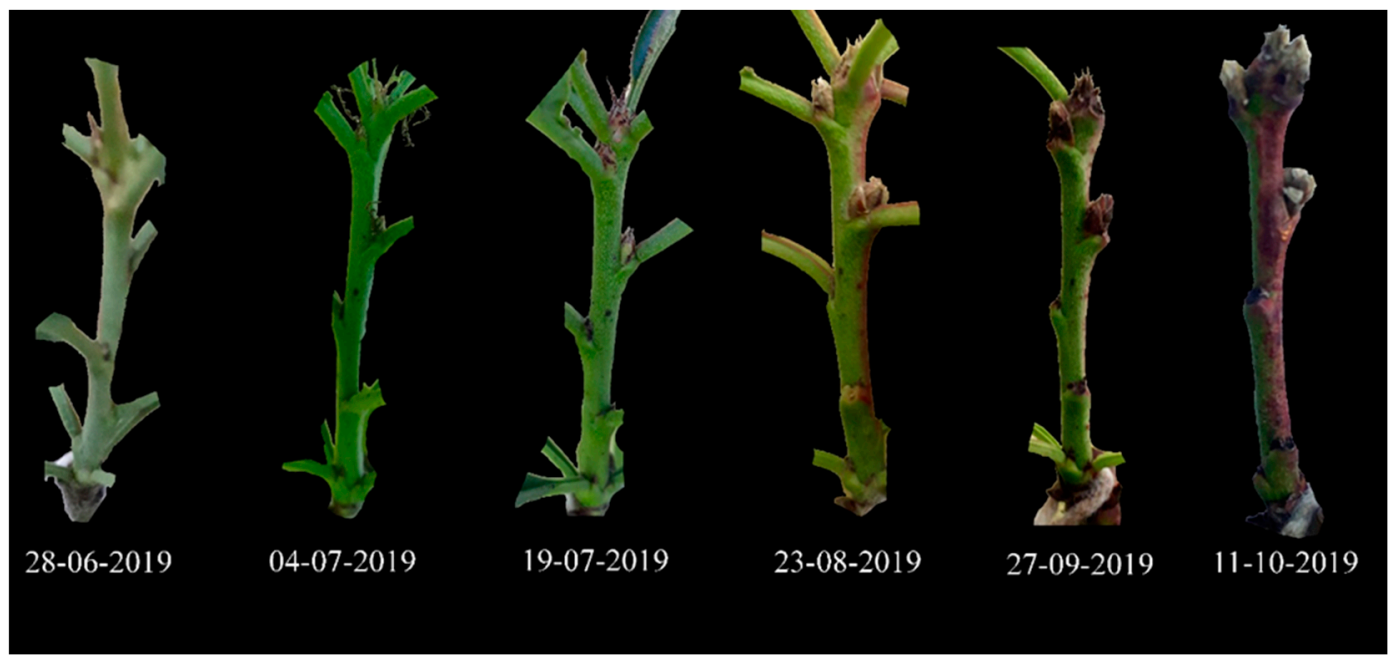

Figure 2. Shoot and bud development of the peach cultivar "BRS Kampai" in the tropical area Minas Gerais State, Brazil. The images correspond to the same shoot on six dates from June to October.

After fruit ripening, the tree remains in a vegetative state that coincides with the end of the summer, lasting up to the beginning of fall. The specific timing of these events depends on the cultivar and the environmental conditions (Figure 2). During this period of vegetative activity, the plant accumulates reserves to endure the dormancy period and promote the formation of new structures over the following growth cycle [22,34-36]. In response to the meteorological conditions of temperature and photoperiod reduction, the tree enters dormancy $[28,37]$.

In subtropical and tropical conditions, the harvesting period can be advanced to early spring, shortening the period between flowering and harvest to 80-90 days [38-40], in contrast to temperate 
regions, where this period lasts more than 90 days [6,22]. The advancement of the flowering season [33] and the shortening in the phase between flowering and fruit ripening are accompanied by changes in other development processes such as the period of flower bud formation and development [33,41].

\section{Flower Induction}

Flower induction is the process by which environmental and hormonal stimuli originating outside the shoot apex induce physiological changes that lead to the initiation of flower primordia and differentiation $[42,43]$. The time of floral induction depends on the cultivar and the physiological condition of the tree which is affected by weather, site conditions, and cultural practices. It may even vary depending on branch location in the tree [44].

Since the establishment of the hypothesis of the existence of the flower inducing, hormone-like, molecule called "florigen", suggested by Chailakhan in 1930 [45], efforts have been made to clarify the process and factors related to the formation of flower structures and flowering. The process has been studied in a number of plant species over eight decades [22,23,46-55]. However, considering its complexity in terms of genetic, hormonal, and environmental interaction, the process is still not completely understood.

Flower induction is the first event indicating the transition from the vegetative to the reproductive phase, in which a series of tissue changes takes place [50]. This process occurs with no visible external indications. When flower induction begins, the process may no longer be reversed, although it may be harmed when the plant is subject to stress factors [31].

One of the first events that initiate flowering morphogenesis is the perception by the plant of environmental signals, mainly temperature and photoperiod, which may interrupt vegetative growth [55-61]. Thus, the development of the blade of the last leaf formed before the perception of short days may be aborted [23]. In subtropical and tropical regions photoperiod changes are smaller during the year compared to temperate regions, which may result in changes in the response of this stimulus perception by fruiting plants [62].

Peach stipules (Figure 3) develop and evolve into scales (cataphylls), which later cover the buds protecting them during the winter period (Figure 1c). The flower structure formation takes place at the same time (Figure 2); thus, the future buds are protected from adverse environmental conditions [59]. Abscission of stipules may be considered one of the first visible morphological indications preceding the flower differentiation process [63].

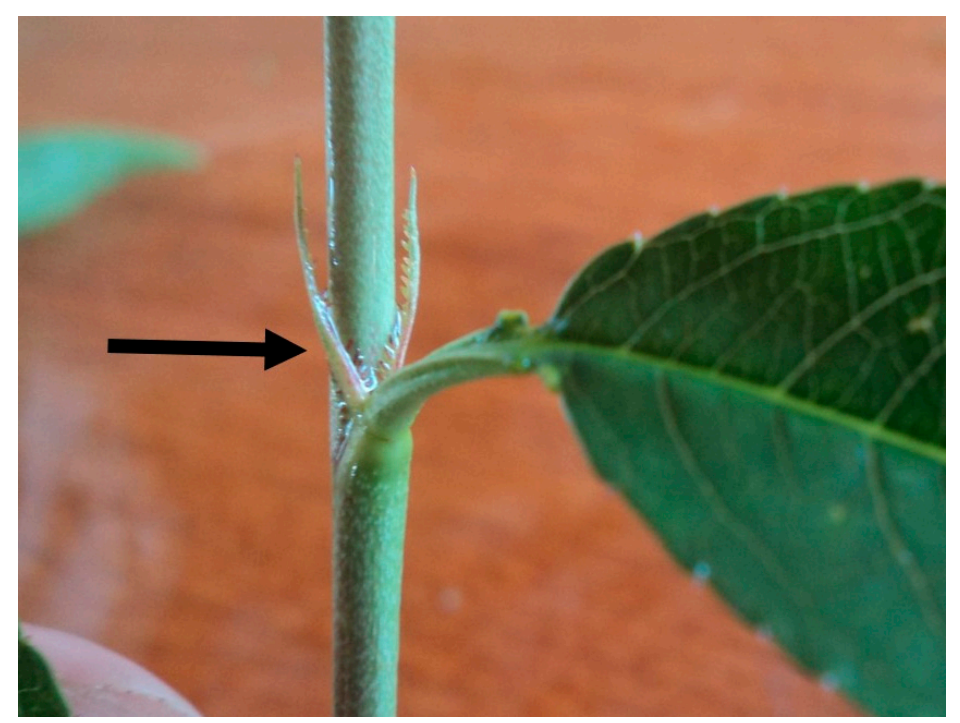

Figure 3. Presence of stipules (indicated by arrow) in peach which are modified leaves with a protecting function. 
In recent years, different genes and other protein complexes have been related to the regulation of seasonal flowering in Prunus spp. [64-67], although this process is not fully understood. The perception of the change in the photoperiod occurs through photoreceptor phytochromes (PHYA, PHYB1, and $P H Y B 2$ ) [65]. They are sensitive to the reduction in photoperiod and, thus, interrupt the vegetative growth and the synthesis of gibberellins (GAs) which, in turn, is communicated to genes such as LATE ELONGATED HYPOCOTYL (LHY) and TIMING OF CAB EXPRESSION 1 (TOC1) (downregulation conditions) for the formation of proteins and genes of the FLOWERING LOCUS T ( $F T$ ) compound, which is responsible for flowering [31,68-75]. These processes have been identified in apricot [76]. Some of these homologs (FLORICAULA/LEAFY) have been identified and characterized in peach [77].

The onset of this process, triggered by the photoreceptors and flowering genes present in the leaves, determines the expression of signals that are sent to the meristems to start tissue dedifferentiation [78]. Peach trees may be sensitive to photoperiod alteration during the period before flowering, which gradually triggers the onset of dormancy, showing alterations of more than 42 proteins associated with photoperiod and dormancy [55].

The biochemical signals reach the meristem through the phloem. Therefore, this is a systemic process with a direct participation of the companion cells connected to the phloem, where the formation of FT-INTERACTING PROTEIN1 (FTIP1) occurs. This is an essential protein located in the endoplasmic reticulum, which interacts with $F T$ to assist its transportation from the companion cells of the phloem to the elements of the sieve plate up to the meristem [31,52,79-85]. The FT protein reaches the meristem where it interacts with the transcription factor bZIP FD or with other counterparts, inducing the expression of APETALA1 (AP1) and SUPPRESSOR OF OVEREXPRESSION OF CONSTANS1 (SOC1) to initiate flower development $[86,87]$. However, these signals are not yet elucidated for most Prunus species. Arabidopsis mutants with early flowering and induction through long days have showed an increased expression of two FT-activating genes, $S O C 1$ and $A P 1$, revealing that both events may be related to the FT $[73,87]$. In early peach cultivars under tropical conditions, the smaller photoperiod alteration and the high temperatures occurring from the beginning of vegetative growth may favor floral induction $[4,6,12]$.

Flower initiation is characterized by the change in the gene activity revealed by the increase in the mRNAs production in apical meristems [88], but also by metabolic changes that induce the subsequent differentiation of the buds $[10,49,52]$. An example is the increase in the concentrations of gibberellins (GAs), cytokinin, and auxins [89].

An important factor that seems to directly influence the transition between the phases of flower initiation and differentiation is the carbon/nitrogen relationship $(C / N)$. When $C / N$ is moderate, the high flower induction occurs, but if it is low, vegetative growth is promoted [80,90]. An inverse relationship between vegetative growth and the formation of flower buds has been reported as well as between vegetative growth and fruit set [14].

Reduction of flower induction, although to a lesser extent, may also occur due to the fact of an unbalanced or low nutritional status which causes a large reduction in the concentration of carbohydrates and, therefore, the $\mathrm{C} / \mathrm{N}$ relationship. Consequently, an imbalance in vegetative growth may occur affecting the formation of buds $[80,90]$. An excessive fruit load in the previous season may affect the $\mathrm{C} / \mathrm{N}$ relationship, reducing plant reserves, especially in late-ripening cultivars in which the maturation of fruits coincides with flower induction. It can even cause competition among organs for carbohydrates, since final fruit growth immediately precedes flower bud initiation, which is a factor contributing to alternate production in unmanaged fruit trees [91-97].

The embryos of developing fruits stimulate the formation of GAs, which are used in the subsequent germination process. However, an excessive fruit load may cause a high concentration of this hormone during the period of flower differentiation for the following cycle, which may cause a reduction in the number of flower buds [82,93].

An excessive fruit load, especially in early-ripening cultivars or in warmer regions, results in an earlier harvest in comparison to temperate and cold regions $[5,6,31,33]$. This early maturation often 
results in a post-harvest imbalance in the tree that leads to the appearance of new vegetative flushes, which also are affected by high-temperatures and water availability [31]. However, these new flushes compete with the formation of flower buds, the number of which can be reduced $[56,94,98]$ (Figure 4 ).

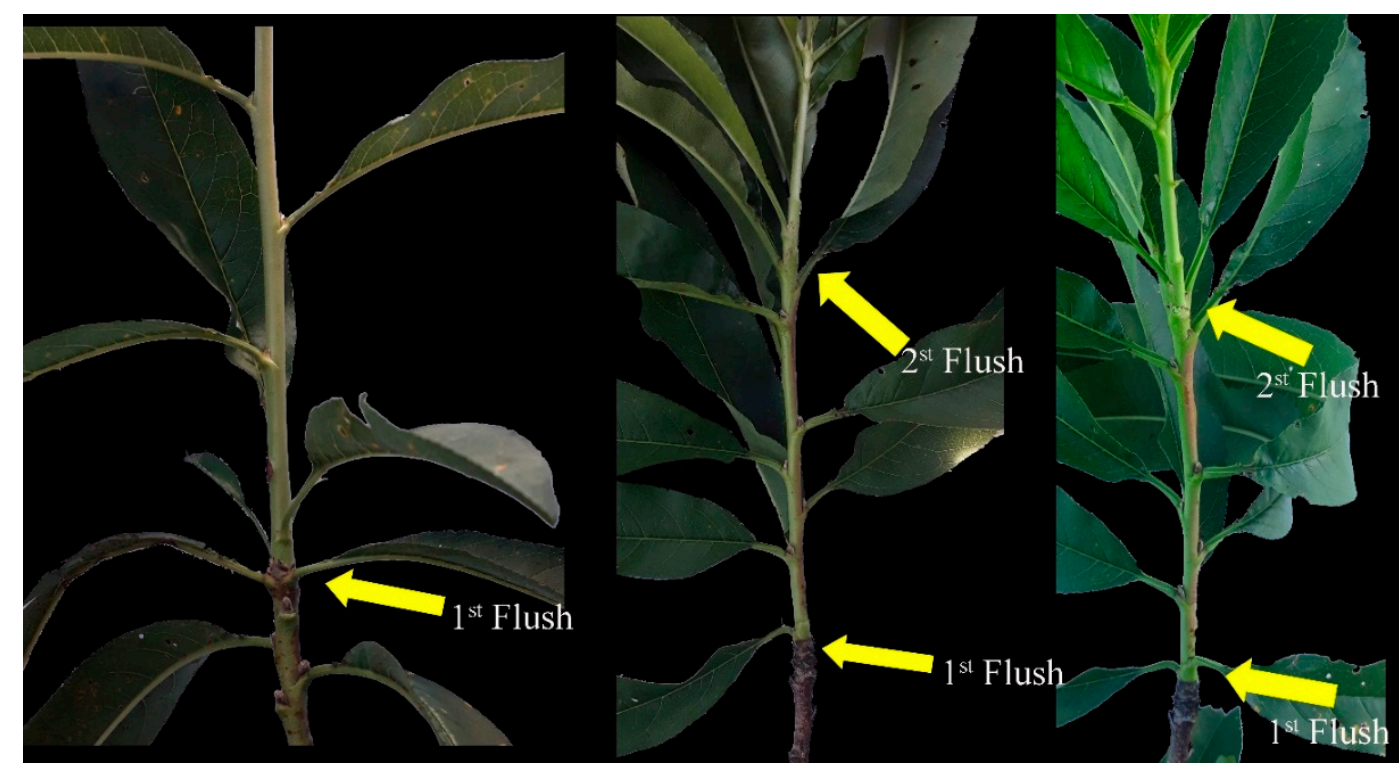

Figure 4. The arrows indicate occurrence of plant growth flushes after fruit harvesting grown in a tropical climate region, Minas Gerais State, Brazil.

The presence and activity of leaves is essential for flower induction, since they are responsible for intercepting and translating the environmental signals, producing and redistributing both assimilates and the hormones responsible for the flower induction process [80]. On the contrary, when the activity of leaves is reduced or an early fall is produced due for example to diseases, this may negatively affect the formation of flower buds $[99,100]$.

\section{Flower Differentiation}

After floral induction, the process of floral differentiation starts, showing the first visible morphological changes $[23,65]$. This is manifested by changes in the size and shape of the apical meristem, which takes on a large, low dome shape, since it transitions from a vegetative meristem to a reproductive meristem. During flower differentiation, it is possible to observe the floral receptacle inside the flower bud, with all the different whorls differentiated: sepals, petals, stamens and pistil.

Flower differentiation and primordial development occur with well-defined steps in late summer and autumn under traditional growing conditions in temperate zones, [22] and even under subtropical climate conditions under differentiated management [42]. However, with the release of new peach cultivars and the expansion of the crop to new areas, especially those in a tropical climate, the timing of these steps is shortened due to the more intense heat accumulation which results in the advancement of floral differentiation [34,101,102].

The vegetative growth interruption before winter dormancy is essential for the survival of temperate plants during low winter temperatures. This occurs in agreement with the cycle of the so-called circadian cycle of the plant $[60,81,98,103,104]$. The growth interruption is initially controlled by photoperiod with the onset of shorter days, when the length of the day is below the critical limit adequate for growth $[55,104]$, and is thought to be one of the key factors for the process of floral differentiation to begin [78].

The flower differentiation process is characterized by morphological changes to the meristem irreversibly forming a flower $[23,42,70,105]$. The progress of the flower bud differentiation is similar for all Prunus species. The flower whorls differentiate during the autumn, and the flower bud enters 
dormancy with its development halted in late autumn or winter [34,101]. In sweet cherry, dormancy occurred at the same stage of flower development, characterized by the presence of all flower whorls, with the anthers clearly differentiated in the four locules, and the pistil showing an incipient ovary, style and stigma [102]. In peach, petals, sepals, corolla and style are also formed at the beginning of dormancy. After dormancy, the buds swell, burst and flower rapidly. The last structures formed are the anthers with the pollen grains, and the ovary, which completed its formation shortly before pre-blossoming [10]. Finally, at flowering, flowers complete their development at anthesis, with the petals opened completely, the stigma receptive, and the anthers dehiscing their pollen [22,23].

In summary, the differentiation of floral buds in peach is an extremely complex process that involves genetic, hormonal and environmental interactions, and does not occur in response to a single pathway but to different stimuli, varying greatly depending on the weather conditions of the areas $[32,49,82,106]$.

\section{Endogenous Factors Involved in Flower Morphogenesis}

Several endogenous factors are involved in the flowering process, including gene expression and suppression, hormonal concentration and balance, and concentration and transportation of carbohydrates $[49,70,71,85]$.

\subsection{Genetic Control}

More than 70 genes are involved in the flowering process in different plant species, which span perception of environmental stimuli, morphological changes in meristem tissues, transportation of carbohydrates, and other functions [107]. A series of proteins and hormones, as well as their transportation, are also involved in this process $[65,66,82,85]$, as well as a series of free polyamines that express themselves during floral development in peach [108].

Most of the research related to the identification of genetic and metabolic processes involved in flowering has been conducted using model species such as Arabidopsis, tomato and rice $[78,87]$.

Although these species present rather distinct characteristics than the perennial fruit species, some key genes responsible for flowering are preserved in perennial species $[31,82,109,110]$ and more recently there have been greater efforts to clarify the process in fruit plants, especially in Prunus spp. and other Rosaceae $[52,65,66,77,88,93,111]$. Thus, some studies have been reported in almond (P. dulcis), sweet cherry (P. avium), apricot (P. armeniaca), and peach [66,77,112-114].

The main genes involved in peach flower bud formation are closely linked to so-called MADS-box, which control the dormancy process in general, and its different phases. This set of genes and their interactions regulate the dormancy process, which starts with the floral induction $[66,77,93,112-116]$. It is assumed that flower induction occurs through a biochemical signal [74] related to an increase in the mRNA production $[52,65,117,118]$. This has been also described in peach, reporting an intensive production of mRNA in the apical meristem at the onset of flower initiation. [52,108].

The activation of some genes responsible for the onset of flower development occurs in response to changing environmental conditions, especially photoperiod and/or temperature $[59,75,119]$, which condition flowering time in Prunus [120]. These changes activate the FLC genes, or their homologues depending on the species. In peach, DAM (SVP-like) is expressed under conditions of gradual temperature reduction during the phase between disruption of vegetative growth and dormancy $[115,121,122]$. The remaining question in tropical or even subtropical regions, where it is less cold and the temperature change is less intense, is whether the signaling and stimulation are strong and clear enough to activate these genes. If this is not the case, it may be necessary to artificially manipulate some factors such as photoperiod, temperature or water deficit. There is evidence of activation of these genes by increasing the concentration of abscisic acid which is formed under stress conditions and can be accumulated by the isolated or joint action of stress factors [123-125]. 


\subsection{Role of Phytohormones}

Phytohormones perform a wide range of roles in plants, acting in signaling, as regulators, promoters, etc. They are also involved in the flowering process, although their roles and functions have not yet been fully clarified, due to their complex functions and interactions. The biochemical signal may also be the result of a change in balance between the concentrations of gibberellins (GAs), cytokinins and auxins [89], since gibberellins inhibit the differentiation of flower buds [82]. In addition, phytohormones interact with the environment, causing diverse combinations and responses. These interactions are complex and poorly understood in traditional peach growing conditions and can even be more complex in tropical weather conditions.

\subsubsection{Gibberellins}

Gibberellins (GAs) are the most influential phytohormones in the flowering process, and, therefore, are the most studied. GAs act on reproductive development and affect the transition from the juvenile to the reproductive stage. In addition, they are involved in flower induction and fruiting [85,86,124-129]. However, they are strong inhibitors in the flowering process of fruit trees [82], since they inhibit the activation of $F T$ compounds [71,129].

One of the key factors for the transition from the vegetative to the reproductive stage is the interruption of the synthesis of GAs in meristems. For the activation of $F T$ and other genes involved in the flowering process to occur, the concentration of active GAs in meristems must be low; otherwise, vegetative growth will not cease, and the flowering process will not begin [130].

The inhibition of flower bud formation is influenced by GAs. Endogenous GAs levels are closely related to cultivars with vigorous growth. Environmental conditions promoting vigorous vegetative growth may favor an increase in the concentration of GAs, resulting in inhibition of the formation of flower buds [52,80,82,101], which is common in the Brazilian subtropical regions.

Applications of GAs have caused inhibition of flower bud differentiation in peach [129] and other fruit trees [126,131]. The sprays of GAs in peach with the aim of reducing the fruit load of the plant (alternative thinning) have also reduced the formation of flower buds in the subsequent cycle in temperate conditions [86,129].

Since excessive vegetative growth in peach inhibits the formation of flower buds, vegetative vigor can be controlled by the application of growth reducers, or by the use of low vigorous rootstocks in different species [86,129-138]. In peach, the application of paclobutrazol has resulted in an increase in the formation of peach flower buds "J.H. Hale" and "Red Skin" in different regions of Iran [135]. Likewise, dwarf rootstocks, which lead to the reduction of the endogenous concentration of GAs and other hormones, enhancing flower bud formation [134-136], have been used for peach in different countries $[133,135,136,139,140]$, although their use is still reduced in Brazil.

\subsubsection{Cytokinins}

Cytokinins appear to be involved in flower induction. However, their role is not as clear as those of other phytohormones, and there is little information available. Apparently, cytokinin has a greater effect in the induction or anticipation of the mitotic process of long-day plants, acting in the apical meristem; whereas, GAs seem to have a more relevant role regarding the regulation of the flowering process in short-day plants [74,141-146].

Cytokinin applications do not induce flowering itself, although they may be part of flower initiation. Exogenous applications of cytokinin trigger the activation of mitosis [145,147]. However, the application of cytokinin in apple for consecutive years induced a reduction in the length of the branches, increased the proportion of spur branches $(<5 \mathrm{~cm})$ and the flowering rate [110]. An increase in the expression of $F T$ and $A F L$ genes, which are responsible for flowering, was also observed. In addition, it reduced the expression of TFL1, which is a flower induction inhibitor [110]. One of the major problems related to the low response of cytokinin applications to induce flowering may be related to the response 
time of the plant. As described in previous studies in Arabidopsis, the response to cytokinin occurs in the long term with repeated applications throughout the cycle of the plant $[14,77,110]$.

Cytokinin may take part in the regulation of the $S O C 1$ gene $[145,147]$. When there is an increase in the FT gene expression in the meristem, there also appears to be an increase of cytokinin and a greater expression of SOC1 in the meristem [144]. The relationship among the actions of cytokinin on the FT florigen is not yet clear, although it has been reported that when FT is activated in the leaves, the cytokinin level is maintained or not increased. However, this is the response obtained in long-day plants $[145,147,148]$, in which the cytokinin is transported through the phloem to the apical meristem when flower stimulation occurs $[117,148]$.

\subsection{Carbohydrates and Their Interactions with Other Endogenous Factors}

One of the remarkable metabolic changes in the transition from the vegetative to the reproductive stage is the increased concentration of starch in the meristems which occurs mainly due to the high demand for sucrose during vegetative growth $[82,149,150]$. Since the interruption of vegetative growth occurs while leaves are photosynthetically active, there is an increase in the concentration of sucrose in the meristem [150]. Due to the reduced demand for vegetative growth in this phase, there is a greater availability of free sucrose. However, in order to avoid waste and maintain reserves, the plant converts the sucrose into starch, increasing the concentration of carbohydrate reserves in the meristems $[58,149]$.

The starch increase in the meristems during the interruption of growth favors the reduction of the activity of GAs, which participate in the action of some enzymes responsible for the degradation of starch such as $\alpha$-amylase. Since the action of GAs is reduced, a reduced action of $\alpha$-amylase can also contribute to an increase in the concentration of starch in the meristem [151].

The vegetative growth interruption and the inhibition of the synthesis of growth promoters occur in the meristem, which is especially notable in relation to the synthesis of GAs through the inactivation of GA 20-Oxidase genes $[58,60,81,109,119,132,152]$. The entire route of GA action during the transition phase from vegetative growth to the establishment of dormancy has been described in detail [153]. The interruption in the synthesis of GAs and possibly of auxins may be mediated by the change in the expression of genes $P H Y, L H Y$, and LEAFY. Thus, vegetative growth is interrupted, allowing the expression of CONSTANS (CO) and leading to increase the activity of genes FLOWERING LOCUS T (FT), SUPRESSOR OF OVEREXPRESSION OF CO1 (SOC1) CO/FT1 and TERMINAL FLOWER 1, 2 (TFL1, 2), and $L E A F Y(L F Y)$, which are responsible for the transition to flower initiation $[75,81,109,119,153]$.

In Prunus spp., flower buds are physiologically active during dormancy, with an intense accumulation of starch in the ovary cells of flower primordia. In sweet cherry, starch accumulates following the same pattern as chilling accumulation, reaching a maximum at chilling fulfillment. This starch subsequently vanishes after dormancy break concomitantly with ovary development before bud burst in the spring [36]. Since starch accumulation in the ovary primordia occurred concomitantly with chilling accumulation, lack of winter chilling could result in failures in starch accumulation, as it has been observed in sour cherry twigs grown in controlled temperature chambers [154]. Starch accumulation in the flower primordia during winter dormancy plays a clear role in subsequent flower development and in the reproductive process in different fruit species such as apricot [155], avocado [156], and sweet cherry [43].

Peach trees cultivated in warm conditions, such as tropical regions, tend to experience an early and shorter cycle, with a period of 80-90 days from flowering to ripening, reaching harvest in spring or early summer. Although apparently this would result in a longer period to accumulate reserves before dormancy, in tropical conditions of high temperatures, long days and availability of water, multiple vegetative growth flushes occur (see Section 3, Figure 4). Therefore, in these conditions there is no interruption of the factors responsible for the paralysis of vegetative growth (see Section 3), which can cause a reduction in the content of reserves to maintain metabolism during floral tissue formation and dormancy. 


\section{Exogenous Factors Affecting Flower Morphogenesis}

Throughout the flower bud lifespan, different external factors may affect flower morphogenesis. These may occur during flower induction, early flower differentiation or the late development of the flower buds in the days before flowering.

\subsection{Techniques for Controlling Tree Growth}

Excessive vegetative growth compromises the development of other organs including flower buds [157-159]. Under environmental conditions that favor greater growth, such as in subtropical and tropical regions, it is necessary to use techniques to assist in the management of canopies to balance growth and the formation of reproductive structures $[83,159]$. This type of management represents one of the main costs in some fruit crops [56].

Several methods have been used for tree growth control including dwarfing rootstocks or winter and summer pruning [159]. However, the use of these techniques must be well planned so not to produce undesirable effects. If they are performed in an unbalanced manner, they will negatively influence fruit production and may even to cause a reduction in the formation of flower buds and imbalance in the photosynthetic capacity of the tree [160].

Although the use of pruning for growth control is efficient, it can be expensive, so other options for controlling growth have been sought. Thus, growth regulation through the use of chemical products has been widely employed, such as chlormequat chloride, daminozide, ethephon, paclobutrazol, prohexadione-calcium, and trinexapac-ethyl $[158,159,161,162]$. Most of them act as inhibitors to the synthesis of GAs, and some induce the formation of ethylene [159,161]. One of these compounds, ethephon, when applied to the branches and other plant tissues reduces the level of auxins in the branch apical meristems, thereby reducing growth $[159,163]$.

Gibberellins inhibitors, such as paclobutrazol, prohexadione-calcium, and trinexapac-ethyl, act on different stages of GA biosynthesis, avoiding the formation of more active GAs. Chlormequat chloride blocks the action of key enzymes that start the synthesis of GAs. In Brazil the only compounds registered for use in fruit trees are prohexadione-calcium and paclobutrazol [159]. Active GAs are responsible for the extension and growth of branches. The immediate precursor to active GAs is $G_{20}$, which is biologically inactive. However, through the action of enzyme $\mathrm{GA}_{20-3}, \mathrm{GA}_{20}$ is converted to the more active form $\mathrm{GA}_{1}$ [159]. Prohexadione-calcium was developed for controlling vegetative growth $[164,165]$. It acts on the enzyme $\mathrm{GA}_{20-3}$, reducing the formation of $\mathrm{GA}_{1}$, and has been widely used for vegetative growth control in apple and pear due to the fact of its low toxicity and limited persistence with a low risk to the consumer and environment. However, it has a short duration of activity and more than one application is often necessary [56,159,163-166].

Paclobutrazol inhibits the biosynthesis of GAs, interfering during the initial stages of the kaurene oxidation route, preventing the formation of ent-kaurenol, ent-kaurenal, and ent-kaurenoic acid, and preventing the formation of active GAs $[56,161]$. It has been widely used to induce flowering in mango and olive, among others, both with leaf and soil application, and the latter is considered to be the most efficient method $[56,161,162]$ but requires a great amount of care due to the fact of its high persistency that requires constant dose adjustment due to the residual effect [161,162].

Trinexapac-ethyl significantly reduces the concentration of active $\mathrm{GA}_{1}$, inhibiting the action of the 3b-hidroxilase enzyme, and increasing the $\mathrm{GA}_{20}$ biosynthesis precursor [167]. Although it has been used to control the growth of wheat, sugarcane, and other grasses, its use in fruit crops is still limited, and further studies on its effects are necessary [163].

Even with the wide use of these phytoregulators to control plant growth in fruit trees, such as apple and mango, further information is necessary to determine their effects on other species, especially in peach cultivation in tropical conditions, where different problems related to plant growth interruption have been encountered. Likewise, the establishment of more responsive doses and the determination of adequate time of application under different conditions are needed. 


\subsection{Environmental Factors}

Control of flowering is highly conditioned by the environment and its variability [23,31,53,79,83,105,168,169]. Any disturbances or stresses occurring during the flower induction period may have subsequent consequences in the initiation and differentiation of buds, for instance, reducing the number of flowers per node after a warm and dry summer [170]. High temperatures can also cause an adverse effect creating anomalies in the formation of buds $[9,14,15]$. The exposure of plants for certain periods to milder temperatures, usually below 18-20 ${ }^{\circ} \mathrm{C} / 15-12{ }^{\circ} \mathrm{C}$ day/night, is essential to interrupt plant growth and for flower induction and dormancy progression $[57,171]$. The exposure of these temperature regimens facilitates to interrupt the synthesis of GAs in meristems in addition to making them more sensitive to compounds that promote flowering [171].

Temperature affects most biochemical and metabolic processes. Usually, temperatures slightly over $25^{\circ} \mathrm{C}$ tend to accelerate the metabolism and the differentiation of buds. However, temperatures between 30 and $35^{\circ} \mathrm{C}$ can interrupt the formation of buds, or even cause bud abortion [169,172]. The differentiation of cherry flower buds is slightly accelerated when grown in warmer and more humid areas [105]. Knowing the relationship between temperature and flower differentiation is key for the development of cultivation practices that reduce the temperature during this developmental stage. The use of irrigation or screens may soften damage caused by high temperatures [15,100].

Growth interruption of some peach tree cultivars was observed when maintained for a certain period at temperatures above $25^{\circ} \mathrm{C}$. When the exposure time was long, flower buds were aborted during the differentiation process, creating blind nodes [12]. Similar situations may be common in tropical regions, where trees are usually subject to temperatures above $30{ }^{\circ} \mathrm{C}$ in this phase, often showing the formation of blind nodes (Figure 5) [15].

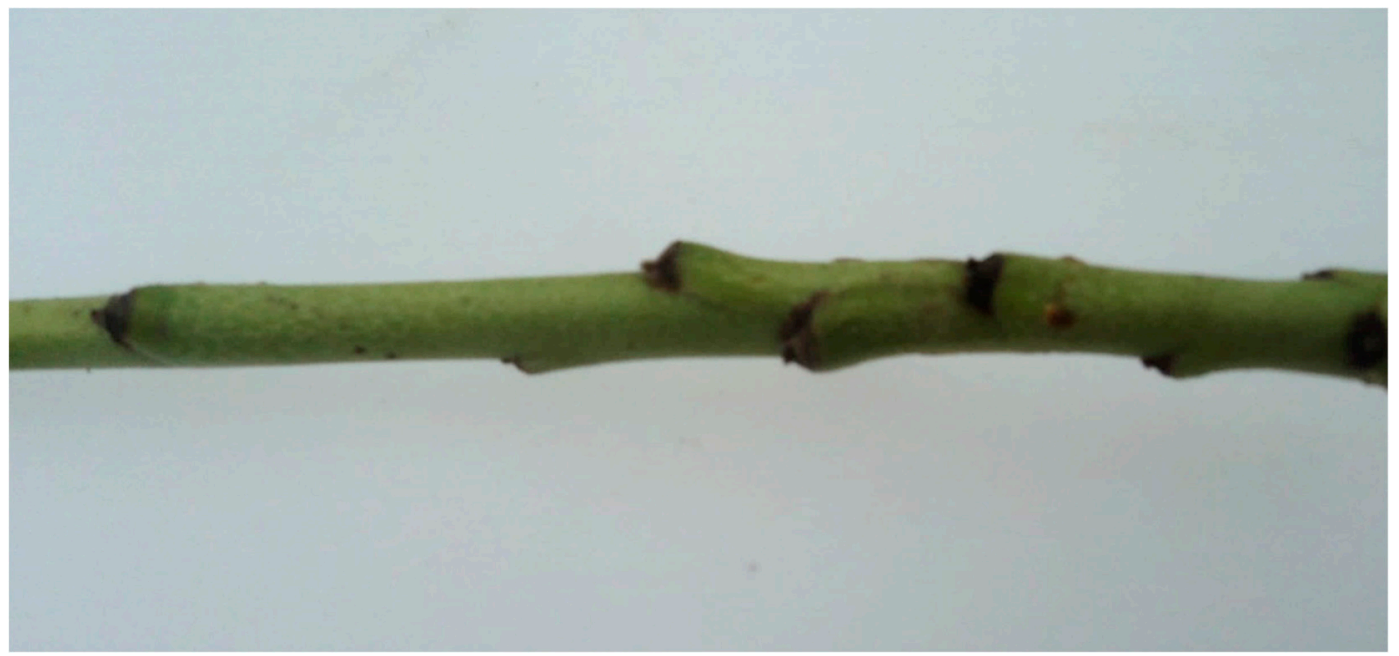

Figure 5. "Blind nodes" in a peach twig, resulting of flower bud abortion due to high temperatures during the differentiation process.

In most fruit tree species, high temperatures cause an increase in the respiratory and transpiration rates, inhibit photosynthesis and cause intensive energy expenditure [14]. In peach, temperatures equal to or higher than $31^{\circ} \mathrm{C}$ during the first two weeks of summer have negative effects on fruit production [173]. High temperatures during the night increase the respiratory rate, causing a reduction in the energy available for some metabolic processes such as the formation of flower buds [14,172]. In sweet cherry temperatures over $30^{\circ} \mathrm{C}$ during flower differentiation caused anomalies resulting in the formation of double pistils [169]. In apricot, the shade caused by the canopy may cause disorders in the induction and differentiation of buds, influencing the final number of buds or even the fruit production the next season [174]. An increase in pre-blossom temperatures accelerated flower bud development 
in apricot, caused a hastening in flowering time and reduced fruit set. The flowers exposed to warmer conditions weighed less and showed less development of the pistil than control flowers [120].

Although other species of the Rosaceae family are insensitive to photoperiod, Prunus spp. can be affected by photoperiod and temperature, indicating that changes in these environmental signals may induce the change from the vegetative to the reproductive phase [57]. Water availability may be another limiting factor for the formation of buds, since this phase generally coincides with high temperatures, and a water deficit when the tree has the largest possible leaf area can cause rapid dehydration of the buds [98,175].

In conditions of low humidity, the tree tends to increase the stomatal closure to reduce water loss by evapotranspiration. Depending on the intensity of water stress, the stomatal closure may be complete causing a drastic reduction in the photosynthetic activity affecting plant growth and is one of the first processes to be interrupted $[56,94,175]$. In these conditions, the respiration of the plant increases, which causes a high energy expenditure, and if that occurs in the flower differentiation phase, it can cause a severe reduction of the reserves available for buds which can abort $[98,175]$. In almond, a reduction in the density of buds was observed in warmer and drier areas [170]. On the other hand, though water availability and warm temperatures facilitate plant growth, they can impair flower induction [175].

Controlled water stress conditions have been used to promote flower induction in fruit trees such as mango and citrus in tropical regions without a significant reduction of flower induction $[174,175]$. This technique interrupts the growth of the tree, leading to an inhibition in the biosynthesis of GAs and makes meristems more sensitive to the action of flowering promoters. However, no in-depth knowledge is available regarding its use in temperate plants, such as peach, for the flower bud formation process. Although this technique can be very useful in peach in tropical areas, there is no information on its use in temperate fruit species.

\section{Conclusions}

The process of flower bud formation in peach differs among areas depending on the climatic conditions. Although the main steps of flower development are maintained, the timing in which each one occurs is different and some processes can be altered under low winter chilling conditions with a significant impact on crop management and fruit production. Further studies on flower bud induction and differentiation under warmer conditions are fundamental for addressing the problems in peach production in different future scenarios: a) the declining of winter chilling caused by climate change in many regions; and b) the interest in expanding peach cultivation to tropical and subtropical areas to obtain earlier fruit and lengthen the harvest period. Promising results in peach production have already been obtained under warmer conditions. However, there are still a number of problems that must be solved, mainly those associated with alterations during the process of flower induction and flower differentiation, which can result in a decrease in the number of flower buds and negatively impact the harvest of the next season. In the next few years, horticulturalists and scientists have to face several challenges, mainly how high temperatures affect the expression of the main genes regulating flower formation and how to improve crop management in these conditions.

Author Contributions: Writing-original draft preparation: G.A.P. and I.C.; writing-review and editing: G.A.P., I.C., S.S.; C.E.M.d.S., A.W.J., C.H.B., J.R. All authors have read and agreed to the published version of the manuscript.

Funding: This research was funded by Ministerio of Ciência, Tecnologia, Inovações e Comunicaçõs of Brazil, through Conselho Nacional de Desenvolvimento Científico - CNPQ in Brazil, and Coordenação de Aperfeiçoamento de Pessoal de Nível Superior - Brasil (CAPES) - Finance Code 001; Ministerio de Ciencia, Innovación y Universidades-European Regional Development Fund, European Union: Instituto Nacional de Investigación y Tecnología Agraria y Alimentaria (grant numbers RFP2015-00015-00, RTA2017-00003-00); and Gobierno de Aragón-European Social Fund, European Union (Grupo Consolidado A12_17R).

Conflicts of Interest: The authors declare no conflict of interest. 


\section{References}

1. Food and Agriculture Organization of the United Nations (FAO) Faostat. Available online: http://faostat3. fao.org/browse/Q/QC/E (accessed on 16 June 2019).

2. Lopez, G.; De Jong, T.M. Spring temperature have a major effect on early stages of peach growth. J. Hortic. Sci. Biotechnol. 2007, 82, 507-512. [CrossRef]

3. Wert, T.W.; Wilianson, J.G.; Chaparro, J.X.; Miller, E.P.; Rouse, R.E. The influence of climate on fruit shape of four low-chill peach cultivars. HortScience 2007, 42, 1589-1591. [CrossRef]

4. Ghrab, M.; Mimoun, M.B.; Masmoudi, M.M.; Mechila, N.B. Chilling trends in a warm production area and their impact on flowering and fruiting of peach trees. Sci. Hortic. 2014, 178, 87-94. [CrossRef]

5. Silva, D.F.P.; Matias, R.G.P.; Silva, J.O.C.; Salazar, A.H.; Bruckner, C.H. Characterization of White-fleshed peach cultivars grown in the 'Zona da Mata' area of Minas Gerais state, Brazil. Comun. Sci. 2016, 7, 149-153. [CrossRef]

6. Ghrab, M.; Zitouna, R.; Masmoudi, M.M.; Mechila, N.B. Phenology and Yield Efficiency of Early, Mid-, and Late-Maturing Cultivars of Peach in Irrigated Orchards under Mediterranean Climate. Int. J. Fruit Sci. 2016, 16, 323-334. [CrossRef]

7. Matias, R.G.P.; Bruckner, C.H.; Silva, D.F.P.; Carneiro, P.C.S.; Oliveira, J.A.A. Adaptability and stability of peach and nectarine cultivars in subtropical climate. Rev. Ceres 2017, 64, 516-522. [CrossRef]

8. Citadin, I.; Raseira, M.C.B.; Herter, F.G.; Silva, J.B. Heat requirement for blooming and leafing in peach. HortScience 2001, 36, 305-307. Available online: http://hortsci.ashspublications.org/content/36/2/305 (accessed on 2 December 2018). [CrossRef]

9. Penso, G.A.; Citadin, I.; Scariotto, S.; Danner, M.A.; Sachet, M.R. Genotype-environment interaction in the density of peach buds cultivated in a humid subtropical climate. Rev. Bras. Frutic. 2018, 40, 1-11. [CrossRef]

10. Nava, G.A.; Dalmago, G.A.; Bergamaschi, H.; Paniz, R.; Santos, R.P.; Marodin, G.A.B. Effect of high temperatures in the pre-blooming and blooming periods in ovule formation, pollen grains and yield of 'Granada' peach. Sci. Hortic. 2009, 122, 37-44. [CrossRef]

11. Couto, M.; Raseira, M.C.B.; Herter, F.G.; Silva, J.B. Influence of high temperatures at blooming time in pollen production and fruit set of peach 'Maciel' and 'Granada'. Acta Hortic. 2010, 872, 225-230. [CrossRef]

12. Monet, R.; Bastard, Y. Effets d'une température modérément élevée: $25^{\circ} \mathrm{C}$, sur les bourgeons floraux du pêcher. Physiol. Veg. 1971, 9, 209-226.

13. Dennis, F.G., Jr. Flowering, fruit set and development under warm conditions. In Temperate Fruit Crops in Warm Climates, 1st ed.; Erez, A., Ed.; Springer: Norwell, MA, USA, 2000; Chapter 5; pp. 101-122.

14. Faust, M. Physiological considerations for growing temperate-zone fruit crops in warm climates. In Temperate Fruit Crops in Warm Climates, 1st ed.; Erez, A., Ed.; Springer: Norwell, MA, USA, 2000; Chapter 7; pp. 137-156.

15. Willianson, J.G.; Wert, T.W.; Chaparro, J.X.; Miller, P.; Rouse, R.E. Flower and vegetative bud set of four low-chill peach cultivars at three locations in Florida. Proc. Fla. State Hortic. Soc. 2008, 121, 46-48.

16. Werner, D.J.; Mowrey, B.D.; Chaparro, J.X. Variability in flower bud number among peach and nectarine clones. HortScience 1988, 23, 578-580.

17. Raseira, M.C.B.; Franzon, R.C. Melhoramento genético. In Pessegueiro; Raseira, M.C.B., Pereira, J.F.M., Carvalho, L.C., Eds.; DF, Embrapa: Brasília, Brazil, 2014; Chapter 4; 776p.

18. Dozier, W.A.; Powell, A.A., Jr.; Caylor, A.W. Hydrogen cyanamide induces budbreak of peaches and nectarines following inadequate chilling. HortScience 1990, 25, 1573-1575. [CrossRef]

19. George, A.P.; Nissen, R.J. Effects of water stress, nitrogen and paclobutrazol on flowering, yield and fruit quality of the low-chill peach cultivar, 'Flordaprince'. Sci. Hortic. 1992, 49, 197-209. [CrossRef]

20. Erez, A.; Yablowitz, Z.; Korcinski, R. Temperature and chemical effects on competing sinks in peach bud break. Acta Hortic. 2000, 514, 51-58. [CrossRef]

21. Erez, A.; Crane, O. Coping with Global Warming Effects on Reduced Winter Chilling for Deciduous Fruit Trees. Available online: https://www.mdpi.com/journal/agronomy/special_issues/fruit_nut_tree_phenology. (accessed on 6 December 2019).

22. Warriner, C.L.; Johnson, J.L.; Smith, M.W. Comparison of the initiation and development of 'Redhaven' peach flowers in standard and meadow orchard trees. J. Am. Soc. Hortic. Sci. 1985, 110, 379-383.

23. Engin, H.; Ünal, A. Examination of flower bud initiation and differentiation in sweet cherry and peach by scanning electron microscope. Turk. J. Agric. For. 2007, 31, 373-379. 
24. Hedhly, A.; Hormaza, J.H.; Herrero, M. Global warming and sexual plant reproduction. Trends Plant Sci. 2009, 14, 30-36. [CrossRef]

25. Campoy, J.A.; Egea, D.R.J. Dormancy in temperate fruit trees in a global warming context: A review. Sci. Hortic. 2011, 130, 357-372. [CrossRef]

26. Sage, T.L.; Bagha, S.; Lundsgaard-Nielsen, V.; Branch, H.A.; Sultmanis, S.; Sage, R.F. The effect of high temperatures stress on male and female reproduction in plants. Field Crop. Res. 2015, 182, 30-42. [CrossRef]

27. Gray, S.B.; Brandy, S.M. Plant developmental responses to climate change. Dev. Biol. 2016, 419, 64-77. [CrossRef] [PubMed]

28. Castro, L.A.S.; Barbieri, R.L. Botânica e morfologia do pessegueiro. In Raseira MCB; Pereira, J.F.M., Carvalho, G.L.C., Eds.; DF, Embrapa: Brasília, Brazil, 2014; Chapter 2; 776p.

29. Borba, M.R.C.; Scarpare Filho, J.Á.; Kluge, R.A. Teores de carboidratos em pessegueiros submetidos a diferentes intensidades de poda verde em clima tropical. Rev. Bras. Frutic. 2005, 27, 68-72. [CrossRef]

30. Gordon, D.; Damiano, C.; De Jong, T.M. Preformation in vegetative buds of Prunus persica: Factors influencing number of leaf primordial in overwintering. Tree Physiol. 2005, 26, 537-544. [CrossRef] [PubMed]

31. Samach, A.; Smith, H. Constraints to obtaining consistent annual yields in perennials. II: Environment and fruit load affect induction of flowering. Plant Sci. 2013, 207, 168-176. [CrossRef] [PubMed]

32. Okie, W.R.; Werner, D.J. Genetic influence in flower bud density in peach and nectarine exceeds that of environment. HortScience 1996, 31, 1010-1012. [CrossRef]

33. Souza, F.; Alves, E.; Pio, R.; Castro, E.; Reighard, G.; Freire, A.I.; Mayer, N.A.; Pimentel, R. Influence of temperature on the development of peach fruit in a subtropical climate region. Agronomy 2019, 9, 20. [CrossRef]

34. Reinoso, H.; Luna, V.; Pharis, R.P.; Bottini, R. Dormancy in peach (Prunus persica) flower buds. V. Anatomy of bud development in relation to phenological stage. Can. J. Bot. 2002, 80, 656-663. [CrossRef]

35. Della Bruna, E.; Moreto, A.L. Desenvolvimento dos frutos de pêssegos 'Aurora' e nectarina 'Sunraycer' no sul de Santa Catarina. Rev. Bras. Frutic. 2011, 485-492. [CrossRef]

36. Fadón, E.; Herrero, M.; Rodrigo, J. Dormant flower buds actively accumulate starch over winter. Front. Plant Sci. 2018, 9, 1-9. [CrossRef]

37. Fadón, E.; Rodrigo, J. Unveiling winter dormancy through empirical experiments. J. Exp. Bot. 2018, 152, 28-36. [CrossRef]

38. Raseira, M.C.B.; Nakasu, B.H.; Pereira, J.F.M. 'BRS Libra': Cultivar de pessegueiro lançada pela Embrapa, em 2009. Rev. Bras. Frutic. 2010, 32, 1272-1274. [CrossRef]

39. Scariotto, S.; Citadin, I.; Raseira, M.C.B.; Sachet, M.R.; Penso, G.A. Adaptability and stability of 34 peach genotypes for leafing under Brazilian subtropical conditions. Sci. Hortic. 2013, 155, 111-117. [CrossRef]

40. Citadin, I.; Scariotto, S.; Sachet, M.R.; Rosa, F.J.; Raseira, M.C.B.; Wagner, A., Jr. Adaptability and stability of fruit set and production of peach trees in a subtropical climate. Sci. Agric. 2014, 71, 133-138. [CrossRef]

41. Santos, J.A.; Costa, R.; Fraga, H. Climate change impacts on thermal growing conditions of main fruit species in Portugal. Clim. Chang. 2017, 140, 273-286. [CrossRef]

42. Barbosa, W.; Campo-Dall'orto, F.A.; Ojima, M.; Sampaio, V.R. O pessegueiro no sistema de pomar compacto: III. Épocas de poda drástica na diferenciação floral. Bragantia 1990, 49, 147-155. [CrossRef]

43. Fadón, E.; Herrero, M.; Rodrigo, J. Flower development in sweet cherry framed in the BBCH scale. Sci. Hortic. 2015, 192, 141-147. [CrossRef]

44. Herrero, M.; Rodrigo, J.; Wunsch, A. Flowering, Fruit Set and Development. In Cherries: Botany, Production and Uses; Quero-García, J., Iezzoni, A., Puławska, J., Lang, G., Eds.; CAB International: Boston, MA, USA, 2017; pp. 14-35. ISBN 9781780648378.

45. Puterill, J.; Varkonyi-Gasic, E. FT and florigen long-distance flowering control in plants. Sci. Hortic. 2016, 33, 77-82. [CrossRef]

46. Galun, E.; Gressel, J.; Keynan, A. Suppression of floral induction by actinomycin D-An inhibitor of 'messenger' RNA synthesis. Life Sci. 1964, 3, 911-915. [CrossRef]

47. Jackson, D.I. Gibberelin and growth of peach and apricot fruits. Aust. J. Biol. Sci. 1968, 21, 209-215. [CrossRef]

48. Monet, R.; Bastard, Y. Lês mécanismes de floraison chez le pêcher. Bull. Tech. Inf. 1970, 248, 173-176.

49. Bernier, G. Structural and metabolic changes in the apex in transition to flowering. Can. J. Botany 1971, 49, 803-819. [CrossRef] 
50. Bernier, G. The control of floral evocation and morphogenesis. Annu. Rev. Plant Phys. 1988, 39, $175-219$. [CrossRef]

51. Lavee, S. Involvement of plant growth regulators and endogenous growth substances in the control of alternate bearing. Acta Hortic. 1989, 239, 311-322. [CrossRef]

52. Andreini, L.; Bartolini, S. Morphological changes in the apex of Prunus persica L. during floral transition and effects of gibberellin in flower bud differentiation. J. Appl. Hortic. 2008, 10, 93-99.

53. Loiseau, M.; Éraud, C.; Tort, M. Influence de la température sur les borgeous végétatifs dormants de pêcher. I-Productions foliaires et caulinaires. Acta Bot. Gallica 2001, 149, 35-40. [CrossRef]

54. Loiseau, M.; Éraud, C.; Tort, M. Influence de la température sur les borgeous végétatifs dormants de pêcher. II-Vitesse D'organogenèse. Acta Bot. Gallica 2002, 149, 35-40. [CrossRef]

55. Li, S.; Tan, Q.; Sol, M.; Xu, G.; Li, C.; Fu, X.; Li, L.; Gao, D.; Li, D. Protein changes in response to photoperiod during dormancy induction in peach leaves and flower buds. Sci. Hortic. 2018, 239, 114-122. [CrossRef]

56. Asín, L.; Alegre, S.; Montserrat, R. Effect of paclobutrazol, proexadione-Ca, deficit irrigation, summer pruning and root pruning in shoot growth, yield, and return bloom, in a 'Branquilla' pear orchard. Sci. Hortic. 2007, 113, 142-148. [CrossRef]

57. Heide, O.M. Interaction of photoperiod and temperature in control of growth and dormancy of Prunus species. Sci. Hortic. 2008, 115, 309-314. [CrossRef]

58. Atkinson, C.J.; Brennan, R.M.; Jones, H.G. Declining chilling and its impact in temperate perennial crops. Environ. Exp. Bot. 2013, 91, 48-62. [CrossRef]

59. Tylewicz, S.; Tsuji, H.; Miskolczi, P.; Peterlle, A.; Azeez, A.; Jonsson, K.; Shimamoto, K.; Bhalerao, R.P. Dual role of tree florigen activation complex component FD in photoperiodic growth control and adaptive response pathways. Proc. Natl. Acad. Sci. USA 2015, 112, 3140-3145. [CrossRef] [PubMed]

60. Ding, J.; Nilsson, O. Molecular regulation of phenology in trees-Because the seasons they are a-changin. Curr. Opin. Plant Biol. 2016, 29, 73-79. [CrossRef] [PubMed]

61. Lloret, A.; Badenes, M.L.; Ríos, G. Modulation of dormancy and growth responses in reproductive buds of temperate trees. Front. Plant Sci. 2018, 9, 1368. [CrossRef] [PubMed]

62. Pio, R.; Souza, F.B.M.; Kalcsits, L.; Bisi, R.B.; Farias, D.H. Advances in the production of temperate fruits in the tropics. Acta Sci. Agron. 2019, 41, e39549. [CrossRef]

63. Almeida, A.L.; Paiva, E.A.S. Colleters in Mabea fistulifera Mart. (Euphorbiaceae): Anatomy and biology of the secretory process. Flora 2019, 258, 151439. [CrossRef]

64. Bielenberg, D.G.; Rauh, B.; Fan, S.; Gasic, K.; Abbott, A.G.; Reighard, G.L.; Okie, W.R.; Wells, C.E. Genotyping by sequencing for SNP-Based linkage map construction and QTL analysis of requirement and bloom date in peach [Prunus persica (L.) Batsch]. PLoS ONE 2015, 10, 1-14. [CrossRef]

65. Yamane, H.; Ooka, T.; Jotatsu, H.; Sasaki, R.; Tao, R. Expression analysis of PpDAM5 and PpDAM6 during flower bud development in peach (Prunus persica). Sci. Hortic. 2011, 129, 844-848. [CrossRef]

66. Sánchez-Pérez, R.; Cueto, J.D.; Dicenta, F.; Martínez-Gómez, P. Recent advancements to study flowering time in almond and other Prunus species. Front. Plant Sci. 2014, 5, 1-7. [CrossRef]

67. Kurokura, T.; Mimida, N.; Battey, N.H.; Hytönen, T. The regulation of seasonal flowering in the Rosaceae. J. Exp. Bot. 2013, 64, 4131-4141. [CrossRef]

68. Rinne, P.; Kaikuranta, P.M.; Schoot, C.V.D. The shoot apical meristem restores its symplasmic organization during chilling-induced release from dormancy. Plant J. 2001, 26, 249-264. [CrossRef] [PubMed]

69. Turck, F.; Fornara, F.; Coupland, G. Regulation and identity of florigen: FLOWERING LOCUS T moves center stage. Annu. Rev. Plant Biol. 2008, 59, 573-594. [CrossRef] [PubMed]

70. Wilkie, J.D.; Sedgley, M.; Olesen, T. Regulation of floral initiation in horticultural trees. J. Exp. Bot. 2008, 59, 3215-3228. [CrossRef] [PubMed]

71. Wellmer, F.; Riechmann, J.L. Gene networks controlling the initiation of flower development. Trends Genet. 2010, 26, 519-527. [CrossRef] [PubMed]

72. Wu, S.; Gallagher, K.L. Transcription factors in the move. Curr. Opin. Plant Biol. 2012, 15, 645-651. [CrossRef] [PubMed]

73. Xing, W.; Wang, Z.; Wang, X.; Bao, M.; Ning, G. Over-expression of an FT homolog from Prunus mume reduces juvenile phase and induces early flowering in rugose rose. Sci. Hortic. 2014, 172, 68-72. [CrossRef]

74. Denay, G.; Chahtane, H.; Tichtinsky, G.; Parcy, F. A flower is born: An update in Arabidopsis floral meristem formation. Curr. Opin. Plant Biol. 2017, 35, 15-22. [CrossRef] 
75. Maurya, J.P.; Bhalerao, R.P. Photoperiod- and temperature-mediated control of growth cessation and dormancy in trees: A molecular perspective. Ann. Bot. 2017, 120, 351-360. [CrossRef]

76. Yarur, A.; Soto, E.; Léon, G.; Almeida, A.M. The sweet cherry (Prunus avium) FLOWERING LOCUS T gene is expressed during floral bud determination and can promote flowering in a winter-annual Arabidopsis acession. Plant Reprod. 2016, 29, 311-322. [CrossRef]

77. Lijun, A.; Lei, H.; Shen, X.; Li, T. Identification and characterization of PpLFL, a homolog of FLORICAULA/LEAFY in peach (Prunus persica). Plant Mol. Biol. Rep. 2012, 30, 1488-1495. [CrossRef]

78. Tan, F.-C.; Swain, S.M. Genetics of flower initiation and development in annual and perennials plants. Physiol. Plantarum. 2006, 128, 8-17. [CrossRef]

79. Tromp, J. Flower-bud formation in apple under various day and night temperature-regimes. Sci. Hortic. 1980, 13, 235-243. [CrossRef]

80. Tromp, J. Flower-bud formation in pome fruits as affected by fruit thinning. Plant Growth Regul. 2000, 31, 27-34. [CrossRef]

81. Bernier, G.; Périlleux, C. A physiological overview of the genetics of flowering time control. Plant Biotechnol. J. 2005, 3, 3-16. [CrossRef]

82. Bangerth, F. Flower induction in perennial fruit trees: Still a enigma? Acta Hortic. 2006, 727, $177-196$. [CrossRef]

83. Wood, B.W. Influence of plant bioregulators in pecan flowering and implications for regulation of pistillate flower initiation. HortScience 2011, 46, 870-877. [CrossRef]

84. Bartolini, S.; Viti, R.; Andreini, L. The effect of summer shading in flower bud morphogenesis in apricot (Prunus armeniaca L.). Cent. Eur. J. Biol. 2013, 8, 54-63. [CrossRef]

85. Taoka, K.; Ohki, I.; Tsuji, H.; Kojima, C.; Shimmamoto, K. Structure and function of florigen and the receptor complex. Trends Plant Sci. 2013, 18, 287-294. [CrossRef]

86. Nakawa, M.; Honsho, C.; Kanzaki, S.; Shimizu, K.; Utsnomiya, N. Isolation and expression analysis of FLOWERING LOCUS T -LIKE and gibberellin metabolism genes in biennial-bearing mango trees. Sci. Hortic. 2012, 139, 108-117. [CrossRef]

87. Nakamura, Y.; Andrés, F.; Kanehara, K.; Liu, Y.C.; Dörmann, P.; Coupland, G. Arabidopsis florigen FT binds to diurnally oscillating phospholipids that accelerate flowering. Nature 2013, 5, 1-7. [CrossRef]

88. Ohmiya, A. Characterization of ABP19/2, sequence homologues of germin-like protein in Prunus persica L. Plant Sci. 2002, 163, 683-689. [CrossRef]

89. Westwood, M.N. Temperate-Zone Pomology-Physiology and Culture, 3rd ed.; Timber Press: Portland, OR, USA, 1993.

90. Mediene, S.; Jordan, M.O.; Pagés, L.; Lebot, J.; Adamowicz, S. The influence of severe shoot pruning in growth, carbon and nitrogen status in young peach trees (Prunus persica). Tree Physiol. 2002, 22, 1289-1296. [CrossRef] [PubMed]

91. Berman, M.E.; De Jong, T.M. Crop load and water stress effects in daily stem growth in peach (Prunus persica). Tree Physiol. 1997, 17, 467-472. [CrossRef] [PubMed]

92. Génard, M.; Lescourret, F.; Gomez, L.; Habbib, R. Changes in fruit sugar concentrations in response to assimilate supply, metabolism and dilution: A modeling approach applied to peach fruit (Prunus persica). Tree Physiol. 2003, 23, 373-385. [CrossRef] [PubMed]

93. Reig, C.; González-Rossia, D.; Juan, M.; Agustí, M. Effects of fruit load on flower bud initiation and development in peach. J. Hortic. Sci. Biotechnol. 2006, 81, 1079-1085. [CrossRef]

94. Dichio, B.; Xiloyannis, C.; Sofo, A.; Montanaro, G. Effects of post-harvest regulated deficit irrigation on carbohydrate and nitrogen partitioning, yield quality and vegetative growth of peach trees. Plant Soil 2007, 290, 127. [CrossRef]

95. Ikinci, A. Influence of pre-and postharvest summer pruning on the growth, yield, fruit quality, and carbohydrate content of early seasons peach cultivars. Sci. World J. 2014, 2014, 104865. [CrossRef]

96. Yu, D.J.; Hwang, J.Y.; Chung, S.W.; Oh, H.D.; Yun, S.K.; Lee, H.J. Changes in clod hardiness and carboydrate contente in peach (Prunus persica) trunk bark and wood tissues during cold acclimation and deacclimation. Sci. Hortic. 2017, 219, 45-52. [CrossRef]

97. Sperling, O.; Kamai, T.; Tixier, A.; Davidson, A.; Jarvis-Shean, K.; Raveh, E.; DeJong, T.M.; Zwieniecki, M.A. Predicting bloom dates by temperature mediated kinetics of carbohydrate metabolism in deciduous trees. Agric. Forest. Meteorol. 2019, 276, 107643. [CrossRef] 
98. Wisniewski, M.E.; Basset, C.L.; Renaut, J.; Farrel, R., Jr.; Tworkoski, T.; Artlip, T.S. Differential regulation of two dehydrin genes from peach (Prunus persica) by photoperiod, low temperature and water deficit. Tree Physiol. 2006, 26, 575-584. [CrossRef]

99. Byrne, D.H.; Wayne, B.; Bacon, T.A. Stone fruit genetic pool and its exploitation for growing under warm winter conditions. In Temperate Fruit Crops in Warm Climate; EREZ, A., Ed.; Kluwer Academic: Dordrecht, The Netherlands, 2000; Chapter 8; pp. 157-230.

100. Alves, G.; May-de-Mio, L.L.; Zanette, F.; Olieira, M.C. Ferrugem do pessegueiro e seu efeito na desfolha e na concentração de carboidratos em ramos e gemas. Trop. Plant Pathol. 2008, 33, 370-376. [CrossRef]

101. Shen, Y.; Guo, J.; Liu, C.; Jia, K. Effect of temperature in the development of peach flower organs. Acta Hortic. 1999, 26, 1-6.

102. Luna, V.; Lorenzo, E.; Reinoso, H.; Tordable, M.C.; Abdala, G.; Pharis, R.P.; Bottini, R. Dormancy in peach (Prunus persica L.) flower buds. I floral morphogenesis and endogenous gibberellins at the end of the dormancy period. Plant Physiol. 1990, 93, 20-25. [CrossRef] [PubMed]

103. Fadón, E.; Rodrigo, J.; Herrero, M. Is there a specific stage to rest? Flower bud development and winter dormancy in sweet cherry (Prunus avium L.). Trees Struct. Funct. 2018, 32, 1583-1594. [CrossRef]

104. Battey, N.H. Aspects of seasonality. J. Exp. Bot. 2000, 51, 1769-1780. [CrossRef] [PubMed]

105. Li, B.L.; Xie, Z.; Zhang, A.; Xu, W.; Zhang, C.; Liu, Q.; Liu, C.; Wang, S. Tree growth characteristics and flower bud differentiation of sweet cherry (Prunus avium L.) under different climate conditions in China. HortScience 2010, 37, 6-13. [CrossRef]

106. Araki, T. Transition from vegetative to reproductive phase. Curr. Opin. Plant Biol. 2001, 4, 63-68. [CrossRef]

107. Zhu, Y.; Li, Y.; Xin, D.; Chen, W.; Shao, X.; Wang, Y.; Guo, W. RNA-Seq-based transcriptome analysis of dormant flower buds of Chinese cherry (Prunus pseudocerasus). Gene 2015, 555, 362-376. [CrossRef]

108. Liu, J.H.; Moriguchi, T. Changes in free polyamines and gene expression during peach flower development. Biol. Plant. 2007, 51, 530-532. [CrossRef]

109. Rinne, P.L.H.; Welling, A.; Vahala, J.; Ripel, L.; Rounala, R.; Kangasjärvi, J.; Schoot, C.V.D. Chilling of dormant duds hyperinduces FLOWERING LOCUS T and recruits GA-inducible 1,3- $\beta$-glucanases to reopen signal conduits and release dormancy in Populus. Plant Cell 2011, 23, 130-146. [CrossRef]

110. Li, Y.; Zhang, D.; Xing, L.; Zhang, S.; Zhao, C.; Han, M. Effect of exogenous 6-benzylaminopurine (6-BA) in branch type, floral induction and initiation, and related gene expression in 'Fuji' apple (Malus domestica Borkh). Plant Growth Regul. 2016, 79, 65-70. [CrossRef]

111. Ohmiya, A.; Tanaka, Y.; Kadowaki, K.; Hayashi, T. Cloning of genes encoding Auxin-Binding Proteins (ABP19/20) from peach: Significant peptide sequence similarity with germin-like proteins. Plant Cell Physiol. 1998, 39, 492-499. [CrossRef] [PubMed]

112. Giannino, D.; Mele, G.M.; Cozza, R.; Bruno, L.; Testone, G.; Ticconi, C.; Frugis, G.; Biotini, M.B.; Innocenti, A.M.; Mariotti, D. Isolation and characterization of maintenance DNA-methyltransferase gene from peach (Prunus persica [L.] Batsch): Transcript localization in vegetative and reproductive meristems of triple buds. J. Exp. Bot. 2003, 54, 2623-2633. [CrossRef] [PubMed]

113. Bielemberg, D.G.; Wang, Y.E.; Li, Z.; Zhebentyayeva, T.; Fan, S.; Reighard, G.L.; Scorza, R.; Abbott, A.G. Sequencing and annotation of the evergrowing locus in peach [Prunus persica (L.) Batsch] reveals a cluster of six MAD-Box transcription factors as candidate genes for regulation of terminal bud formation. Tree Genet. Genomes 2008, 4, 495-507. [CrossRef]

114. Fan, S.; Bielenberg, D.G.; Zhebentyayeva, T.N.; Reighard, G.L.; Okie, W.R.; Holland, D.; Abbott, A.G. Mapping quantitative trait loci associated with chilling requirement, heat requirement and bloom date in peach (Prunus persica). New Phytol. 2010, 185, 917-930. [CrossRef]

115. Hemming, M.N.; Trevaskis, B. Make hay when the sun shines: The Role of MADS-box genes in temperature-dependant seasonal flowering responses. Plant Sci. 2011, 180, 447-453. [CrossRef]

116. Li, H.-F.; Dong, Q.-L.; Jia, H.-Z.; Li, G.-X.; Ran, K. Isolation and expression. Analysis of eight MADS-box genes in peach (Prunus persica var. nectarina 'Luxing'). J. Plant Biochem. Biot. 2018, 27, 435-442. [CrossRef]

117. Giakountis, A.; Coupland, G. Phloem transport of flowering signals. Curr. Opin. Plant Biol. 2008, 11, 687-694. [CrossRef]

118. Mc Garry, R.C.; Kragler, F. Phloem-mobile signals affecting flowers: Applications for crop breeding. Trends Plant Sci. 2013, 18, 198-206. [CrossRef] 
119. Olsen, J.E. Light and temperature sensing and signaling in induction of bud dormancy in wood plants. Plant Mol. Biol. 2010, 73, 37-47. [CrossRef]

120. Rodrigo, J.; Herrero, M. Effects of pre-blossom temperatures on flower development and fruit set in apricot (Prunus armeniaca L.). Sci. Hortic. 2002, 92, 125-132. [CrossRef]

121. Tuan, P.A.; Bai, S.; Saito, T.; Ito, A.; Moriguchi, T. Dormancy-Associated MADS-Box (DAM) and the abscisic acid pathway regulate pear endodormancy through a feedback mechanism. Plant Cell Physiol. 2017, 58, 1378-1390. [CrossRef]

122. Luo, Y.; Li, H.; Xiang, Z.; He, N. Identification of Morus notabilis MADS-box genes and elucidation of roles of MnMADS33 during endodormancy. Nature 2018, 8, 5860. [CrossRef]

123. Yang, Q.; Niu, Q.; Li, J.; Zheng, X.; Ma, Y.; Bai, S.; Teng, Y. PpHB22, a member of HD-Zip proteins, activates PpDAM1 to regulate bud dormancy transition in 'Suli' pear (Pyrus pyrifolia with Pear Group). Plant Physiol. Biochnol. 2018, 127, 355-365. [CrossRef]

124. Taylor, B.H.; Geisler-Taylor, D. Flower bud thinning and winter survival of 'Redhaven' and 'Cresthaven' peach in response to GA3 sprays. J. Am. Soc. Hortic. Sci. 1998, 123, 500-508. [CrossRef]

125. Blake, M.P.S.; Browning, G.; Benjamin, L.J.; Mander, L.N. Gibberellins in seedlings and flowering trees of Prunus avium L. Phytochemistry 2000, 53, 519-528. [CrossRef]

126. Mutasa-Göttgens, E.; Hedden, P. Gibberelin as a factor in floral regulatory networks. J. Exp. Bot. 2009, 60, 1979-1989. [CrossRef] [PubMed]

127. Stern, R.A.; Ben-Arie, R. GA3 inhibits flowering, reduces hand-thinning, and increases fruit size in peach and nectarine. J. Hortic. Sci. Biotechnol. 2009, 84, 119-124. [CrossRef]

128. González-Rossia, D.; Juan, C.R.M.; Agustí, M. Horticultural factors regulating effectiveness of GA3 inhibiting flowering in peaches and nectarines (Prunus persica L. Batsch). Sci. Hortic. 2007, 111, 352-357. [CrossRef]

129. Crane, J.C.; Primer, P.E.; Campbell, R.C. Gibberellin induced parthenocarpy in Prunus. J. Am. Soc. Hortic. Sci. 1960, 75, 129-137.

130. Eriksson, M.E.; Israelsson, M.; Olsson, O.; Moritz, T. Increased gibberellin biosynthesis in transgenic trees promotes growth, biomass production and xylem fiber length. Nature 2000, 18, 784-788. [CrossRef] [PubMed]

131. Basile, B.; Marsal, J.; Solari, L.I.; Tyree, M.T.; Bryla, D.R.; DeJong, T.M. Hydraulic conductance of peach trees grafted on rootstocks with differing size-controling potentials. J. Hortic. Sci. Biotechnol. 2003, 78, 768-774. [CrossRef]

132. Basile, B.; Marsal, J.; De Jong, T.M. Daily shoot extension growth of peach trees growing on rootstocks that reduces scion growth is related to daily dynamics of stem water potential. Tree Physiol. 2003, 23, 659-704. [CrossRef] [PubMed]

133. Weibel, A.; Johnson, R.S.; De Jong, T.M. Comparative vegetative growth responses of two peach cultivars grown on size-controlling versus standard rootstocks. J. Am. Soc. Hortic. Sci. 2003, 128, 463-471. [CrossRef]

134. Pereira, F.M.; Mayer, N.A.; Dall'orto, F.A.C. 'Rigitano': Nova cultivar de umezeiro para porta-enxerto de pessegueiro. Rev. Bras. Frutic. 2007, 29, 172-175. [CrossRef]

135. Arzani, K.; Bahadori, F.; Piri, S. Paclobutrazol reduces vegetative growth and enhances flowering and fruiting of mature 'J.H. Hale' and 'Red Skin' peach trees. Hortic. Environ. Biotechnol. 2009, 50, 84-93.

136. Tworkoski, T.; Miller, S.; Scorza, R. Relationship of pruning and growth morphology with hormone rations in shoots of pillar and standard peach trees. J. Plant Growth Regul. 2006, 25, 145-155. [CrossRef]

137. Ramírez, F.; Devenport, T.L. Mango (Mangifera indica L.) flowering physiology. Sci. Hortic. 2010, 126, 65-72. [CrossRef]

138. De Jong, T.M.; Basile, B.; Marsal, J.; Ramming, D.; Bryla, D. Growth, yield and physiological behavior of size-controlling peach rootstocks development in California. Acta Hortic. 2004, 658, 449-455. [CrossRef]

139. Webster, A.D. Rootstock and interstock effects on deciduous fruit tree vigour, precocity, and yield productivity. N. Z. J. Crop. Hortic. 1995, 23, 373-382. [CrossRef]

140. Tworkoski, T.; Scorza, R. Root and shoot characteristics of peach trees with different growth habits. J. Am. Soc. Hortic. Sci. 2001, 126, 785-790. [CrossRef]

141. Bartrina, I.; Otto, E.; Strnad, M.; Werner, T.; Schmülling, T. Cytokinin regulates the activity of reproductive meristems, flower organ size, ovule formation, and thus seed yield in Arabidopsis thaliana. Plant Cell 2011, 23, 69-80. [CrossRef] [PubMed] 
142. D'Aloia, M.; Bonhomme, D.; Bouché, F.; Tamseddak, K.; Ormenese, S.; Torti, S.; Coupland, G.; Périlleux, C. Cytokinin promotes flowering of Arabidopsis via transcriptional activation of the FT paralogue TSF. Plant J. 2011, 65, 972-979. [CrossRef] [PubMed]

143. Bernier, G. My favorite flowering image: The role of cytokinin as a flowering signal. J. Exp. Bot. 2013, 64, 5795-5799. [CrossRef]

144. Han, Y.; Yang, H.; Jiao, Y. Regulation of inflorescence architecture by citokinins. Front. Plant Sci. 2014, 5, 1-4. [CrossRef]

145. Bonhomme, F.; Kurz, B.; Melzer, S.; Bernier, G.; Jacqmard, A. Cytokinin and gibberellin activate SaMADS A, a gene apparently involved in regulation of the floral transition in Sinapsis alba. Plant J. 2000, 24, 103-111. [CrossRef]

146. Corbesier, L.; Prinsen, E.; Jacqmard, A.; Lejeune, P.; Onckelen, H.V.; Périlleux, C.; Bernier, G. Cytokinin levels, leaf exudate and shoot apical meristem of Arabidopsis thaliana during floral transition. J. Exp. Bot. 2003, 54, 2511-2517. [CrossRef]

147. Moghaddam, M.R.B.; Ende, W.V.D. Sugars, the clock and transition to flowering. Front. Plant Sci. 2013, 4, 1-6. [CrossRef]

148. Du, L.; Qi, S.; Ma, J.; Xing, L.; Fan, S.; Zhang, S. Identification of TPS family members in apple (Malus $\mathrm{x}$ domestica Borkh.) and the effect of sucrose sprays in TPS expression and floral induction. Plant Physiol. Biochnol. 2017, 120, 10-23. [CrossRef]

149. Rinne, P.; Touminem, H.; Juntilla, O. Seasonal changes in bud dormancy in relation to bud morphology, water and starch content, and abscisic acid concentration in adult trees of Betula pubescens. Tree Physiol. 1994, 14, 549-561. [CrossRef]

150. Kim, Y.C.; Nakajima, M.; Nakayama, A.; Yamaguchi, I. Contribution of gibberellins to the formation of Arabidopsis seed coat through starch degradation. Plant Cell Physiol. 2005, 46, 1317-1325. [CrossRef]

151. Karlberg, A.; Englund, M.; Petterele, A.; Molnar, G.; Sjödin, A.; Bako, L. Analysis of global changes in gene expression during activity-dormancy cycle in hybrid aspen apex. Plant Biotechnol. 2010, 27, 1-16. [CrossRef]

152. Felker, F.C.; Robitaille, H.A.; Hess, F.D. Morphological and ultrastructural development and starch accumulation during chilling of sour cherry flower buds. Am. J. Bot. 1983, 70, 376-386. [CrossRef]

153. Rodrigo, J.; Hormaza, J.I.; Herrero, M. Ovary starch reserves and flower development in apricot (Prunus armeniaca). Physiol. Plant. 2000, 108, 35-41. [CrossRef]

154. Alcaraz, M.L.; Hormaza, J.I.; Rodrigo, J. Ovary starch reserves and pistil development in avocado (Persea americana). Physiol. Plant. 2010, 140, 395-404. [CrossRef]

155. Lam-Yam, L.; Parisot, E. Preliminary study on peach floral differentiation in mild winter areas. Acta Hortic. 1990, 279, 231-238. [CrossRef]

156. Ramirez, H.; Alonso, S.; Benavides, A. Proexadione-Ca modifies growth and endogenous hormones in shoot apex in apple trees. Acta Hortic. 2006, 727, 117-124. [CrossRef]

157. Petri, J.L.; Hawerroth, F.J.; Leite, G.B.; Sezerino, A.A.; Couto, M. Reguladores de Crescimento Para Plantas Frutíferas de Clima Temperado; Epagri: Florianópolis, Brazil, 2016; 141p.

158. Gonçalves, M.A.; Cocco, C.; Vignolo, G.K.; Picolotto, L.; Antunes, L.E.C. Efeito da intensidade de poda na produção e qualidade de frutos de pessegueiro. Rev. Bras. Frutic. 2014, 36, 742-747. [CrossRef]

159. Mouco, M.A.C.; Ono, E.O.; Rodrigues, J.D. Inibidores de síntese de giberelinas e crescimento de mudas de mangueira 'Tomy Atkins'. Cienc. Rural 2010, 40, 273-279. [CrossRef]

160. Oliveira, A.F.; Cruz, M.C.M.; Oliveira, D.L.; Mesquita, H.A. Paclobutrazol em oliveira submetida a diferentes regimes hídricos. Semina 2012, 33, 2137-2148. [CrossRef]

161. Greene, D.W. The effect of Proexadione-calcium of fruit set and chemical thinning of apple trees. HortScience 2007, 42, 1361-1365. [CrossRef]

162. Costa, G.; Andreotti, C.; Bucchi, F.; Sabatini, E.; Bazzi, C.; Malaguti, S. Prohexadione-Ca (Apogee $\left.{ }^{\circledR}\right)$ : Growth regulation and reduced fire blinght incidence in pear. HortScience 2001, 36, 931-933. [CrossRef]

163. Greene, D.W. The effect of repeat annual applications of Proexadione-calcium in fruit set, return bloom, and fruit size of apples. HortScience 2008, 43, 376-379. [CrossRef]

164. Evans, J.R.; Evans, R.R.; Regusci, C.L.; Rademacher, W. Mode of action, metabolism, and uptake of BAS 125W, Proexadione-calcium. HortScience 1999, 34, 1200-1201. [CrossRef]

165. Espinula, M.C.; Rocha, V.S.; Souza, L.T.; Souza, M.A.; Campanharo, M.; Grossi, J.A.S. Rates of nitrogen and growth retardant trinexapac-ethyl in wheat. Cienc. Rural 2011, 41, 2045-2052. [CrossRef] 
166. Shu, Z.H.; Sheen, T.F. Floral induction in axillary buds of mango (Mangifera indica L.) as affected by temperature. Sci. Hortic. 1987, 31, 81-87. [CrossRef]

167. Beppu, K.; Ikeda, T.; Kataoka, I. Effect of high temperature exposure time during flower bud formation in the occurrence of double pistils in 'Satohnishiki' sweet cherry. Sci. Hortic. 2001, 87, 77-84. [CrossRef]

168. Kodad, O.; Sociais i Company, R.F. Significance of flower bud density for cultivar evaluation in almond. HortScience 2008, 43, 1753-1758. [CrossRef]

169. Li, Z.; Reighard, G.L.; Abbott, A.G.; Bielemberg, D.G. Dormancy-associated MADS genes from the EVG locus of peach [Prunus persica (L.) Batsch] have distinct seasonal and photoperiodic expression patterns. J. Exp. Bot. 2009, 60, 3521-3530. [CrossRef]

170. Went, F.W. The effect of temperature in plant growth. Ann. Rev. Plant Physiol. 1953, 4, 347-362. [CrossRef]

171. Caprio, J.M.; Quamme, H.A. Influence of weather in apricot, peach and sweet cherry production in the Okanagan Valley of British Columbia. Can. J. Plant Sci. 2006, 86, 259-267. [CrossRef]

172. Albuquerque, N.; Burgos, L.; Egea, J. Influence of flower bud density, flower bud drop and fruit set in apricot productivity. Sci. Hortic. 2004, 102, 397-406. [CrossRef]

173. Shao, H.-B.; Chu, L.-Y.; Jaleel, C.A.; Zhao, C.-X. Water-deficit stress-induced anatomical changes in higher plants. C. R. Biol. 2008, 331, 215-225. [CrossRef] [PubMed]

174. Li, S.H.; Huget, J.G.; Schoch, P.G.; Orlando, P. Response of peach tree growth and cropping to soil water deficit at various phonological stages of fruit development. J. Am. Soc. Hortic. Sci. 1989, 64, 541-552. [CrossRef]

175. Núñez-Elisea, R.; Davenport, T.L. Flowering of mango trees in containers as influenced by seasonal temperature and water stress. Sci. Hortic. 1994, 58, 57-66. [CrossRef]

(C) 2020 by the authors. Licensee MDPI, Basel, Switzerland. This article is an open access article distributed under the terms and conditions of the Creative Commons Attribution (CC BY) license (http://creativecommons.org/licenses/by/4.0/). 